\title{
The Rabbits 230 years on
}

\author{
Hollie Cheung
}

University of Technology Sydney, Faculty of Arts and Social Sciences, PO Box 123, Ultimo NSW 2017, Australia. hollie.cheung@student.uts.edu.au

DOI: https://doi.org/10.5130/nesais.v4i1.1520

The Rabbits, written by John Marsden and illustrated by Shaun Tan, is "a rich and haunting allegory for all ages, all cultures" (Marsden \& Tan 1998). The 32-page picture book is a reference to Australia's colonial past, exploring the history between British colonisers and Australia's Indigenous population.

The Rabbits was published in the politically charged context of 1998, six years after the Mabo case ruling of terra nullius and a year after the release of the Human Rights and Equal Opportunity Commission's 'Bringing Them Home' Inquiry, among calls for a national apology. Upon its release the book received both criticism and acclaim, winning the Children's Book Council of Australia Picture Book of the Year in 1999. It has since been adapted into an award winning opera and continues to be used in both Australian primary and secondary schools. Twenty years since publication and 230 years since colonisation, the themes depicted continue to have relevance today.

As a picture book, the text is representative of Aboriginal history and culture. Picture books are often read aloud and reflect the long oral history tradition of Aboriginal people, while the illustrations mirror Aboriginal art and its layered meanings. Anthropomorphism is employed in The Rabbits, where the rabbits are the colonisers of the British Empire while the numbat-like marsupials are the Aboriginal and Torres Strait Islanders. This animal choice is symbolic and powerful, as the numbats are a native Australian animal while the rabbits are an introduced, invasive species. Tan depicts the rabbits wearing formal, suited clothing, building houses and operating scientific instruments such as telescopes, chemistry sets and cartography of supposed rationality. In such images the text reproduces the binary oppositions of "the 'coloniser' (rabbits) and 'colonised' (numbats): strong, weak; modern, ancient: civilised, primitive; central, peripheral; conqueror, victim,” (Collins-Gearing \& Osland 2010) that perhaps unconsciously perpetuates the colonial ideology and legacy.

Arguably, picture books are targeted at children and one critique of The Rabbits is its unsuitability to be categorised as 'children's literature' (Banerjee 2013). However, as Clark writes, "kids don't want a safe, tired narrative of Indigenous people" (2007, p. 86). While young children may not understand the complexities of The Rabbits, it may serve as a foundation for future knowledge. The Rabbits diverts from a 'safe' narrative when it references the Stolen Generations in the line "and stole our children" (Marsden \& Tan 1998, pp. 24-25). Tan's accompanying illustration of hundreds of kites carrying 
away baby numbats pulled by rabbit operated planes indicates a mass seize of genocidal intent. This is very much reflective of progressive attitudes at the time and the central premise of the Bringing Them Home Commission, a stance which may have lead to the conservative critique that the book was merely "politically correct propaganda" (Tan 2018).

The Rabbits presents a clear theme of environmental degradation through the rabbits' processes of modernisation and industrialisation. The book displays this through progressive illustrations; in the initial pages the land is untouched and colourful with warm browns, reds, blues and pinks. However, the rabbits and their machines slowly transform the environment and the landscape takes on tinges of brown and grey, before the last three pages are pitch black. This is accompanied by Marsden's text "the land is bare and brown ... where are the great billabongs, alive with long-legged birds?" (Marsden \& Tan 1998, pp. 29-31). This gradual contamination and destruction of the land is extremely significant for Aboriginal culture, where an inextricable link exists between the people, the land and the Dreaming (King et al. 2009). The sense of loss is reflective of Indigenous dispossession, denial, terra nullius and the land rights movement that was gaining momentum in the late twentieth century and still continues today. The land appropriation depicted is one that occurs in tandem with loss of Indigenous ways of living and their lives.

The final page of the book presents the rhetorical question "who will save us from the rabbits?" (Marsden 1998, p. 32) to readers, and indeed society, institutions and the government. The use of "us" continues the 'us' and 'them' dichotomy Marsden has employed throughout the book. While an effective tool, there are inherent problems in Marsden speaking from the numbat's viewpoint, adopting an Indigenous standpoint that is not his own and denying and silencing Aboriginal and Torres Strait Islanders. The idea of 'saving' evokes the imperial language of the 'white saviour', who as a Westerner had "the unique power to uplift, edify and strengthen" (Straubhaar 2014, p. 384) Indigenous populations through the civilising mission that sought to save primitives from themselves. Such a standpoint portrays Aboriginal people as victims without agency or self-determination. It is similarly reminiscent of not-so-distant past paternalistic policies of missionisation and the Aboriginal Protection Board, headed by colonialists who claimed to know best for Indigenous people. The text poses an additional question: is Australia post-colonial? Moreton-Robinson (2003) labels Australia not as post-colonial, but as post-colonising, as the colonisers have never left and the structures that dispossessed Indigenous people remain, continuing to deny their original custodianship.

However, Tan's illustration adds a more optimistic dimension to this final page. Bordered by a black frame underneath a sky of stars sit one rabbit and one numbat with their heads cast downwards. Banerjee (2013, pp. 421-422) argues that while Marsden may have envisioned the question to be spoken by the numbats, Tan's illustration "alters the speaking voice so that the final question is posed collectively, in unison, by the original inhabitant and the self-questioning rabbit who has realised the folly of his ways." Framed in this way, the book leaves its audience with hope, highlighting the need for action, self-determination and collaboration to achieve reconciliation, to "save us" all from a dark colonial past. 


\section{References}

Banerjee, B. 2013, 'Utopian Transformations in the Contact Zone: a postman, postcolonial reading of Shuan Tan and John Marsden's The Rabbits', Global Studies of Childhood, vol. 3, no. 4, pp. 418-426. https://doi.org/10.2304/gsch.2013.3.4.418

Clarke, A. 2010, History's Children: History Wars in the Classroom, UNSW Press, Sydney.

Collins-Gearing, B. \& Osland, D. 2010, 'Who Will Save Us From the Rabbits?: Rewriting the Past Allegorically', The Looking Glass: New Perspectives on Children's Literature, vol. 14, no. 2, viewed April 22 2018, <https://www.lib.latrobe.edu.au/ojs/index.php/tlg/article/view/227/225>.

King, R., Smith, H., Pattel-Gray, A., Mooney, J., Johns, A., Hollis, A., Carnegie, E., Johns, D. \& McQueen, K., 2009, Oxford Studies of Religion, Oxford University Press ANZ, Melbourne.

Marsden, J. \& Tan, S. 1988, The Rabbits, Lothian Books, Port Melbourne, VIC.

Moreton-Robinson, A. 2015, 'I Still Call Australia Home: Indigenous belonging and place in a postcolonizing society', The White possessive: property, power, and Indigenous sovereignty, University of Minnesota Press, Minnesota.

Straubhaar, R. 2015, “The stark reality of the 'White Saviour' complex and the need for critical consciousness: a document analysis of the early journals of a Freirean educator', Compare: A Journal of Comparative and International Education, vol. 45, no. 3, pp. 381- 400.

https://doi.org/10.1080/03057925.2013.876306

Tan, S., 2018, The Rabbits, Shaun Tan, viewed April 22 2018, < $\underline{\text { http://www.shauntan.net/books/the- }}$ rabbits.html >. 